\title{
U.S. Geological Survey Programs in Rhode Island
}

\section{U.S. Department of the Interior - U.S. Geological Survey}

The U.S. Geological Survey (USGS), established by Congress in the Organic Act on March 3, 1879, provides geologic, topographic, hydrologic, and biologic information to the Nation. The USGS works in partnership with State and local municipalities and other Federal agencies to produce and disseminate information that is relevant to the economic and environmental well-being of the citizens of Rhode Island.

\section{Water Supply and Use}

Water supplies in Rhode Island are a limited resource. Consulting firms and State and town officials need basic hydrologic data to plan and regulate waterresources development. The USGS, in cooperation with several State and Federal agencies, collects data from an extensive network of surface- and ground-watermonitoring sites. The data from these networks are needed to assess current water availability and predict water availability during drought.
The Scituate Reservoir system (figs. 1 and 2) is the principal source of drinking water for Rhode Island. The USGS, the Providence Water Supply Board (PWSB), and the Rhode Island Department of Environmental Management (DEM) are participating in a program to assess the flow and quality of water in the streams that contribute to the reservoir.

Low-flow estimates provide the basis for formulating surface- and groundwater basin yield estimates. Information about changes in the water-quality conditions of streams that contribute to the reservoir and which subbasins in the watershed are most affected helps the PWSB to improve watershed management practices and to protect water quality at the water-purification plant intake rather than increase treatment of water.

Because Block Island derives its water supply from ponds and wells on the island, protection of the ground-water resources is of paramount concern. The USGS recently studied the ground water

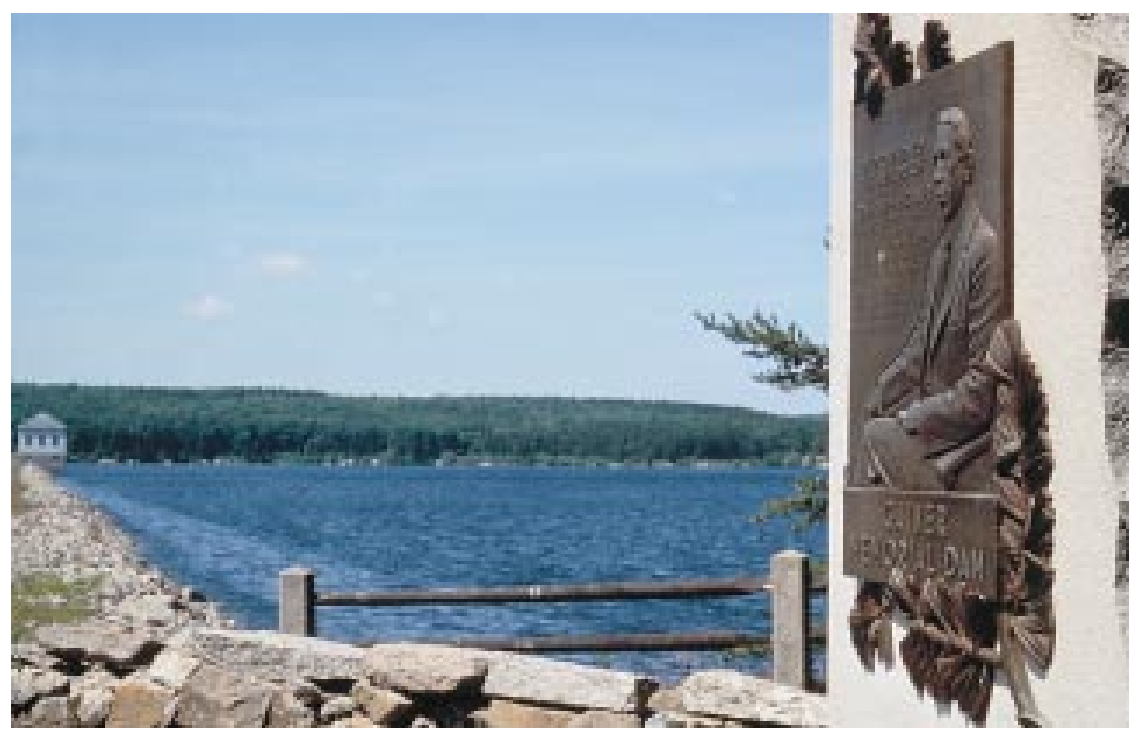

Figure 1. View of the Scituate Reservoir, Rhode Island.

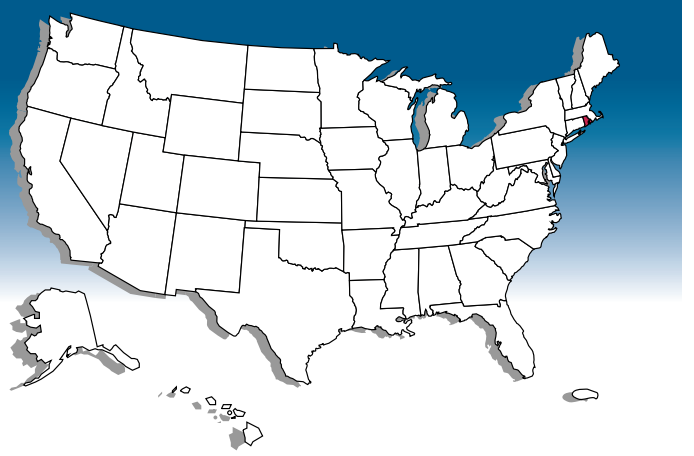

Index of Subjects

Water Supply and Use

Evaluating Human Effects on Water Quality

Radon

Vulnerability of Ground-Water Supplies

Topographic Mapping

Cooperative Programs

Mineral Production Information

Marine and Coastal Research

on the island. Results of the study assisted water-resources managers to determine how much water was available and how it could best be developed.

In the late 1960's, the Rhode Island Water Resources Board (WRB) determined that ground water was the only viable source of additional water for public supply in southern Rhode Island. The USGS, through its 30-year cooperative program with the WRB, has studied ground water in several basins of Rhode Island, including each of five study areas in the Pawcatuck River Basin in southern Rhode Island (fig. 2). These studies identified areas in which hydrogeologic conditions are favorable for development of ground-water supplies and evaluated the effects of ground-water development on water levels and streamflow. The USGS and the WRB are conducting a groundwater investigation of part of the South Branch of the Pawtuxet River Basin, with an emphasis on the 8,600-acre Big River Management Area. The Management Area is maintained as open space. The WRB would like to develop ground-water resources in the Management Area by identifying sites that can produce 1 million gallons per day or more to individual wells as part of an interim water-supply augmentation scheme.

The USGS has developed a water-use data base that describes where, how, and what quantities of water in the State are being used. These data were used in a case 


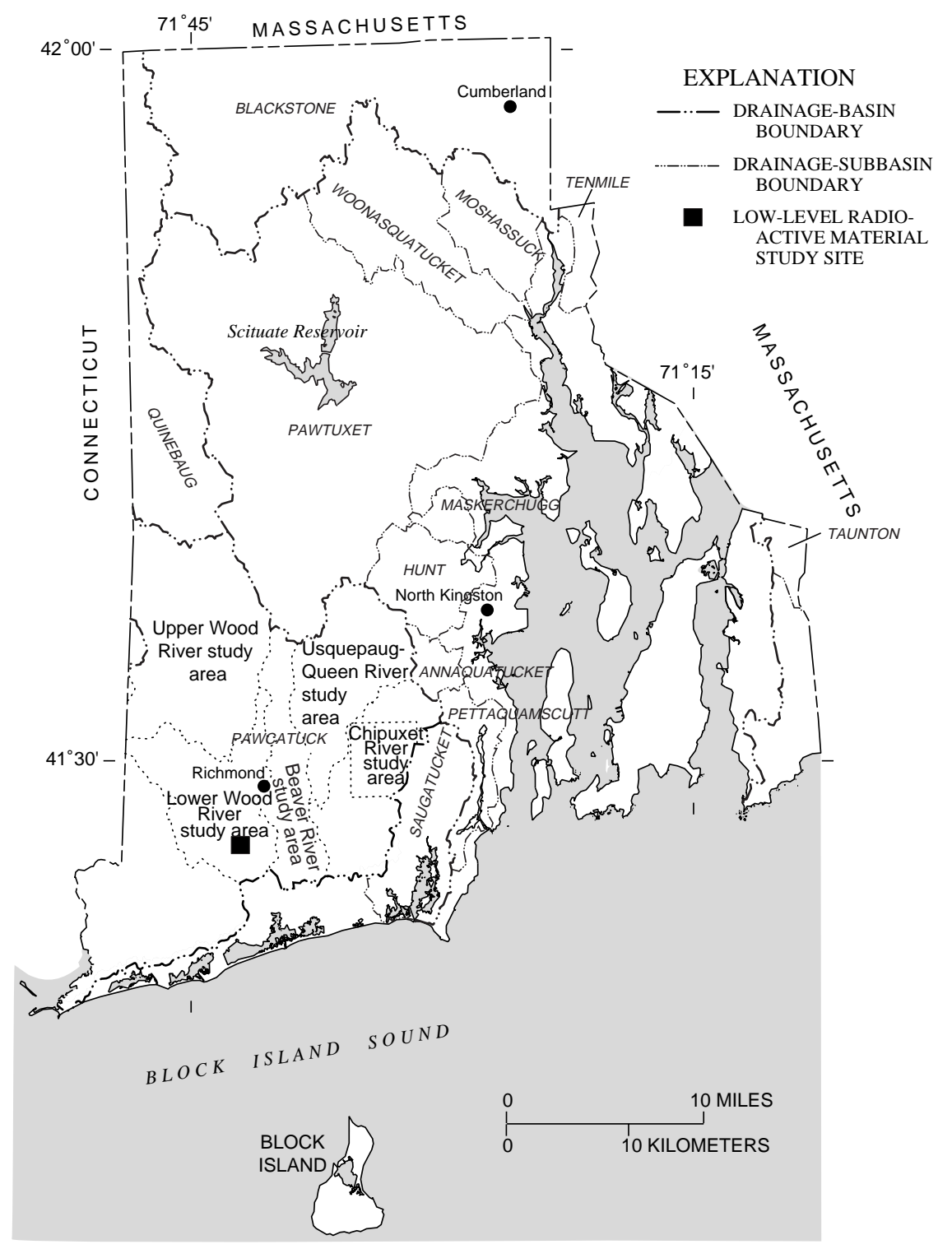

Figure 2. State of Rhode Island watersheds and towns and areas studied by USGS.

study in Cumberland that demonstrated the integration of water-use data collected by State agencies, water suppliers, and wastewater-treatment facilities.

The water demands of many New England communities are reaching operational capacities of current supplies. Furthermore, new sources of water are increasingly difficult to develop because of contamination of water supplies and environmental-protection goals. To augment existing supplies, it is necessary to understand the interaction between water availability and water use, particularly at the regional or basin scale. The USGS, in cooperation with the DEM and North Kingstown, is evaluating water-resource planning alternatives for the Hunt, Annaquatucket, and Pettaquamscutt River Basins. The study is identifying ground-water-development strategies that meet public-supply needs and that minimize the effects of water development on streamflow.

\section{Evaluating Human Effects on Water Quality}

Development throughout Rhode Island has affected water quality. The USGS water-quality-monitoring program provides data that can be used to determine the quality of surface water and the longand short-term trends in water quality; to monitor compliance with Federal and State water-quality standards; and to demonstrate the effects of land-use practices on water quality (fig. 3). The water-quality data are needed by the DEM for complying with Federal monitoring requirements. The USGS state-of-the-art sampling protocols, equipment, and laboratory facilities assure that the State will receive accurate and complete information.

As part of a nationwide research program on ground-water contamination by toxic substances, the USGS conducted an intensive study in an area of southern Rhode Island that was contaminated by liquid wastes from an enriched-uranium cold-scrap recovery plant. Hydrologists sampled the local ground water and mapped an underground plume of lowlevel radioactive contamination (fig. 4). Data collected from 1981 to 1984 indicate that the plume discharged to the Pawcatuck River. Water-quality samples were again collected in 1990 and 1993 to determine how the plume had moved during the intervening years. Computer simulations were used to estimate how long it would take for the contamination to be flushed naturally from the ground-water system and the estimates ranged from 8 to 18 years.

Development of rural areas creates the need to install new septic systems. The ability to predict the highest elevation that the water table will attain is needed

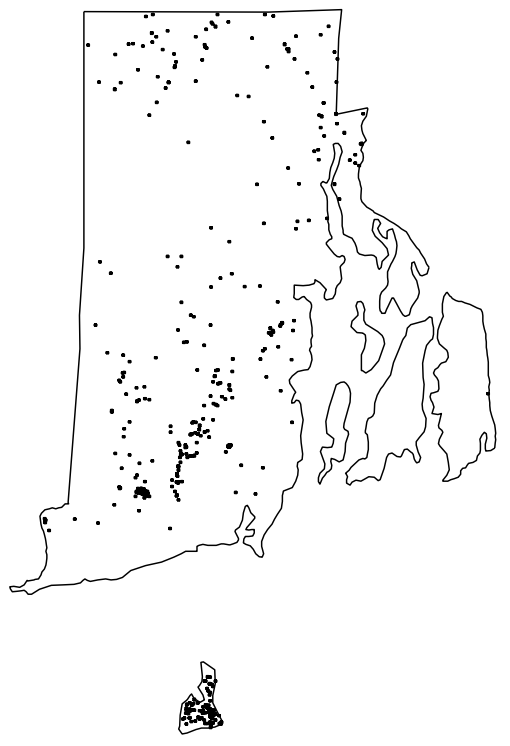

Figure 3. Water-quality data-collection sites. 

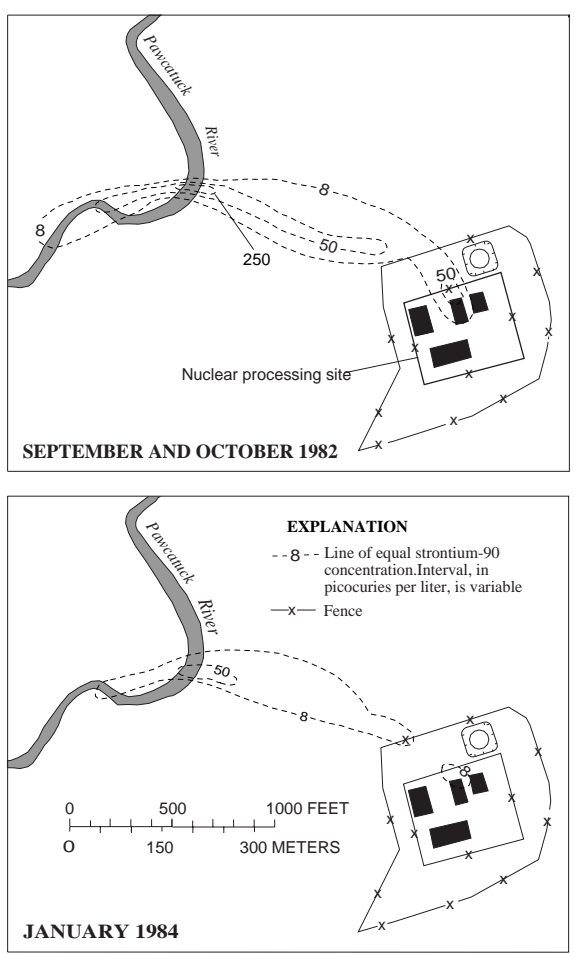

Figure 4. Strontium-90 concentrations in ground water. Location shown in figure 2 .

for ensuring that septic-system leach fields will not be flooded. Ground-water levels typically are highest in the spring and, until recently, almost all proposed septic-system sites in rural areas of the State were required to be tested in the spring. The USGS, in cooperation with the DEM, has developed a method by which a single water-level measurement made at any time during the year at a site of interest can be used to estimate the long-term high water level at that site. The same method can be used to predict the low water level, or the median water level, which is needed for studies of longterm ground-water availability.

\section{Radon}

Faculty and students from the Department of Geology, University of Rhode Island and the State Geologist of Rhode Island are working cooperatively with the USGS to develop a geographic information system (GIS) analysis of surface radioactivity, geology, and the occurrence of indoor radon. This cooperative project is part of a larger effort involving the USGS, the U.S. Department of Energy, and the U.S. Environmental Protection
Agency (USEPA) to develop a method to determine the locations of areas where homes may have radon concentrations that exceed the occupational radiation limit, which is equivalent to 20 picocuries per liter of radon. Measurements of soil/gas radon and gamma-ray activity were made, and samples of soil and rock were collected. The data have been entered into the GIS along with surficial geology information and data from a new bedrock geology map of Rhode Island published by the Office of the Rhode Island State Geologist.

\section{Vulnerability of Ground-Water Supplies}

The USGS, in cooperation with the Rhode Island Department of Health (RIDOH), is conducting a study to classify specific supply systems by their vulnerability to specific classes of natural and manmade constituents including organic compounds, pesticides, and trace elements. This cooperative project is part of a larger effort involving the USGS and the USEPA. Under authority of the Safe Drinking Water Act of 1974, the USEPA promulgates national drinking-water regulations. Recently, the USEPA developed a draft proposal for reforming the chemical monitoring requirements for community water systems (CWS) and nontransient, noncommunity water systems (NTNCWS). The results of the investigations enable RIDOH to define the factors that affect the relative vulnerability of each of the State's CWS and NTNCWS to differing land uses and chemical constituents.

\section{Topographic Mapping}

Among the most popular and versatile products of USGS are its 1:24,000-scale topographic maps ( 1 inch on the map represents 2,000 feet on the ground). These maps depict natural and cultural features of the landscape, such as lakes and streams, highways and railroads, boundaries, and geographic names. Contour lines depict the elevation and shape of terrain. Rhode Island is covered by 37 maps that are used for civil engineering, land-use planning, natural-resource monitoring, and other technical applications. These maps also are favorites with the general public for outdoor uses, including hiking, camping, exploring, and backcountry fishing expeditions.

\section{Cooperative Programs}

The USGS works in cooperation with Federal, State, and local agencies to ensure that data collection and scientific investigations are relevant to public needs. Some current and recent cooperators in the cost-sharing program are: the Rhode Island Department of Environmental Management, the Rhode Island Water Resources Board, the Rhode Island Department of Health; the Providence Water Supply Board; and the Towns of North Kingstown and New Shoreham (Block Island). The USGS provides support to the Rhode Island Water Resources Center, which conducts a program of research, education, and information and technology transfer.

\section{Mineral Production Information}

Rhode Island ranked 48th among the 50 States in nonfuel mineral production in 1995 with an estimated value of $\$ 30$ million. Construction sand, gravel, and crushed stone accounted for most of the nonfuel mineral production in the State. Crushed stone was mostly produced for various construction purposes, although some agricultural limestone was produced.

\section{Marine and Coastal Research}

The USGS conducts a wide range of geological and geophysical research and mapping investigations of continental margins through its Woods Hole Field Center in Massachusetts. From this Field Center, scientists carry out investigations primarily along the U.S. Atlantic coast and in the Gulf of Mexico, the Caribbean Sea, the Great Lakes, and the polar regions. These studies address critical issues in environmental quality and preservation, geologic hazards and public safety, natural resources, global environmental change, and information and technology. The long-range goal is to develop a predictive capability to guide and assess the consequences of the use of the continental margins. 
Storms cause damage to coastal environments; however, the effect of storms on the adjacent inner Continental Shelf is virtually unknown. The USGS, in collaboration with researchers from Columbia University, has been monitoring the effects of hurricanes and large winter storms on this inner shelf environment in Block Island Sound. A large area was imaged in 1991 using sidescan sonar techniques, and it then was surveyed again in 1994 after Hurricane
Bob and two major nor'easters.

Although some changes caused by these storms can be observed, the most dramatic changes are due to the intense fishing in this area. Linear and sinuous furrows caused by trawl doors and dredges have extensively reworked large parts of the sea floor (fig. 5). A better understanding of the extent of this reworking of the sea floor will contribute to better management of the fisheries in Block Island Sound.
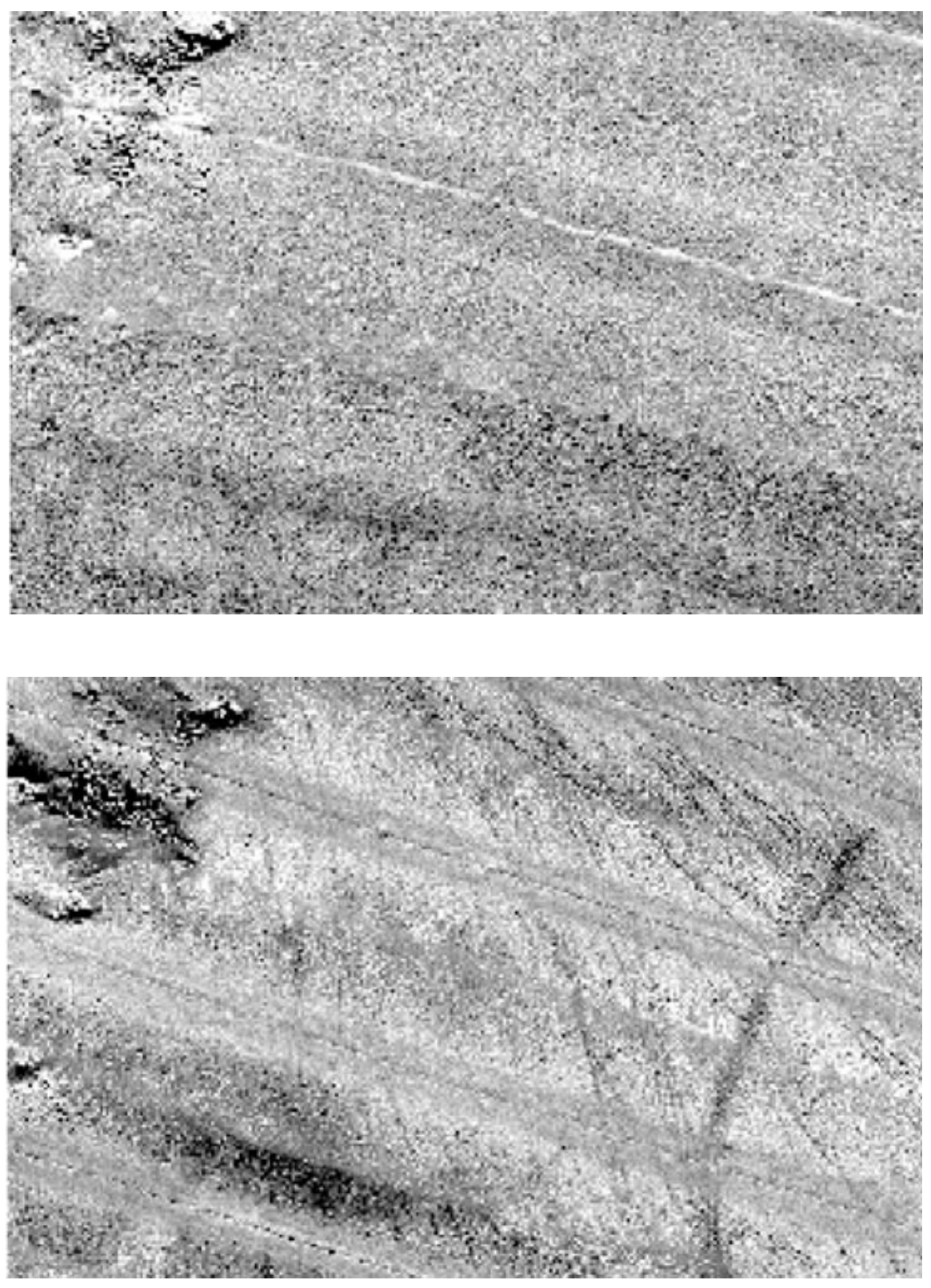

For More Information

USGS state representative 275 Promenade St., Suite 150 Providence, R.I. (401) 331-9050 Fax: (401) 331-9062 Email: oc_ri.usgs.gov

Additional earth science information can be found by accessing the USGS Home Page on the World Wide Web at

http://www.usgs.gov/

For more information on all USGS reports and products (including maps, images, and computerized data), call

1-800-USA-MAPS
Figure 5. Detailed comparison from the 1991 and 1994 surveys of the seabed in an area of Block Island Sound. Note that the same boulders appear in the upper left corner of the image and that trawls marks in the 1994 image are absent in the 1991 image. Images represent an area of 300 by 500 meters
The USGS provides maps, reports, and information to help others meet their needs to manage, develop, and protect America's water, energy, mineral, biological, and land

resources. We help find the natural resources needed to build tomorrow, and supply the scientific understanding needed to help minimize or mitigate the effects of natural hazards and environmental damage caused by natural and human activities. The results of our efforts touch the daily life of almost every American.
U.S. Geological Survey Fact Sheet FS-039-96 